\title{
Laudato Si': Climate Change Action: Si!
}

\author{
Patrick Hutchings ${ }^{1}$
}

Published online: 21 December 2015

(C) Springer Science+Business Media Dordrecht 2015

...it must also be recognised that nuclear energy, biotechnology, information technology, knowledge of our DNA, and many other abilities which we have acquired, have given us tremendous power. More precisely, they have given those with the knowledge, and especially the economic resources to use them, an impressive dominance over the whole of humanity and the entire world. Never has humanity had such power over itself, yet nothing ensures that it will be used wisely, particularly when we consider how it is currently being used.

His Holiness Pope Francis has issued what is probably the one Encyclical, Laudato $\mathrm{Si}$, to get science - empirical science — right. It is about climate change, poverty, and the condition of poor nations under late capitalism. H.H. Pope Francis is said to have studied chemistry, so he knows the difference between hard science which is evidence based and tested, and the Gospels. These are evidence based, but not reportage-in-real-time-at-thetime. And he knows Theology. The evidential status of Theology is - and probably shall remain - a matter of - respectful — debate. If Theology were for St Thomas Aquinas the Queen of the Sciences, 'science' is now ambiguous but the senses can still be sorted out. And need to be. The book of nature is now wide open, and there to be read. Even the notion of what it is to be human can be enriched by the natural sciences. Notions about human sexuality can benefit from re-examination in the light of the biological and social sciences. The sublime St. Thomas Aquinas reconciled the Revelation and Aristotelian philosophy. What we need now is a great number of people, in habits or not, to reconcile the church and Science: notably, to sort out Christian traditions in the light of new knowledge. Some traditions are valuable: Some are merely 'what I say three times is true' stuff. Grain and chaff need careful winnowing.

We all recall the nonsense about Galileo Galilei (1564-1642) whose science could not be reconciled to an Old Testament story: see Joshua 10:12-13, and the scandal of

Patrick Hutchings

sophia@philosophy.unimelb.edu.au

1 School of Historical and Philosophical Studies, University of Melbourne, Melbourne, Australia 
the martyrdom of Giordano Bruno (1554-1600). I still recall, in the twentieth century, Roman Catholic Newman Society debates about Charles Darwin and evolution: this was in the 40s-50s. If God chose to build evolution into His creation, why not? Darwin and Wallace did not invent evolution to annoy biblical literalists; they discovered a fact of nature. Evolution is of course a hypothesis, but it remains so far, not a dismissible one. I recall hearing a cardinal on TV flirting with 'Creationism': a fatuous position, especially so if the Creator is an evolutionist.

In God's good time, H.H. Pope Francis has issued Laudato si': on Care for our Common Home: an Encyclical Letter on Ecology \& Climate. Whether this letter will have been in time, or just in time, the generation after mine shall see. I hope for Heaven, but I am not too confident about the view from there, 50 years from now.

In Chapter 1, §23 H.H. writes:

The climate is a common good belonging to all and meant for all. At the global level, it is a complex system linked to many of the essential conditions of human life. A very solid scientific consensus indicates that we are presently witnessing a disturbing warming of the climatic system...

H.H. Pope Francis adds that this is 'mainly... the result of human activity' and continues, 'The problem is aggravated by a model of development based on the intensive use of fossil fuels [Italic added], which is at the heart of the worldwide energy system'.

In Chapter 1: V. Global Inequality $\S 48, H . H$. Pope Francis remarks:'Both everyday experience and scientific research show that the gravest effects of all attacks on the environment are suffered by the poorest'. H.H. Pope Francis took his Papal name from that St Francis of Assisi (1181/2-1226) who brought the goodness of nature back into focus after a gloomy 'unworldliness' had infected some mediaeval thought. St Francis was poor and aided the poor. He renounced a fortune and became a mendicant friar. Current CEOs are unlikely to do this. Nevertheless, it is an example for a West, which squanders the world's resources, and - literally — darkens the skies.

H.H. Pope Francis is no Malthusian:

To blame population growth instead of extreme and selective consumerism on the part of some, is one way of refusing to face the issues. It is an attempt to legitimate the present model of distribution where a minority believes that it has the right to consume in a way which can never be universalised, since the planet could not even contain the waste products of such consumption.

H.H. Pope Francis - in effect — quotes Immanuel Kant's Categorical Imperative — an Enlightenment ethical notion - itself echoing the Christian 'do as you would be done by' but, putatively, establishing it as quasi-logical as well as an ethical principle.

In the light of the scientific evidence, no Kantian could be a climate change denier. You cannot universalize 'Let us burn coal, oil and so on even though this endangers the planet and all life on it'. Such a maxim would be-in the end-contradictory. Kant thought such contradictions were simply against logic itself. H.H. Pope Francis goes on to use the expression 'ecological debt' incurred by the prosperous: this at the expense of the poor nations who-unlike Bankers-are unlikely to see their due repayment. 
In Chapter $1 \S 52$ we find:

The foreign debt of poor countries has become a way of controlling them. Yet this is not the case where ecological debt is concerned.

In Chapter 1 VI Weak Responses, §53 we find:

The establishment of a legal framework which can set boundaries and ensure the protection of ecosystems has become indispensable; otherwise the new power structures based on the techno-economic paradigm may overwhelm not only our politics but also our freedom and justice.

This gives one a frisson, Trump trumping Washington and Jefferson, F.D.R. and Obama! Under such a presidency, we could not expect much action to reduce climate change.

Chapter 2 is devoted to: II The Wisdom of the Biblical Accounts- $c f \S 65$. This should be read by all religious believers. There is no mytho-rhubarbish stuff about the - alleged - 7 days of creation: only an axiology based on 'God saw everything that he had made, and behold it was very good (Gen 1:31).

Black-letter people and creationists get little support from H.H. 'The biblical texts are to be read in their context with an appropriate hermeneutic...' [Italic added] This is a proper twenty-first century pope: no Pio Nino, he.

Furthermore, the Encyclical on 'modernism' is now démodé. It is as out of date as the steam locomotives which were - as I faintly recall - denounced in it. Curiously, steam trains bear a lot of blame for the pickle we are now in. Lucky shot!

Chapter 3 is required to be read by all economists and politicians: II The Globalisation of the Technocratic Paradigm. This section warns us to beware of neglecting and to ensure 'a more balanced level of production, a better distribution of wealth, concern for the environment and the rights of future generations. [Italic added]

The Encyclical is suffused with what I would like in 'ecological humanism': you do not need to be a Jew, a Christian or a Muslim to see the political excellence of this letter. Humanism-secular humanism—would do. Even John Stuart Mill's utilitarianism would fit in nicely. Pope Francis quotes Pope Benedict XVI's phrase 'an ecology of man' used in an address to the German Bundestag (2011), 'man too has a nature that he must respect and that he cannot manipulate at will' (Chapter 4 §155).

In Chapter $5 \S 169$, H.H. Pope Francis writes 'with regard to climate change, the advances have been regrettably few,' adding:

We believers cannot fail to ask God for a positive outcome to the present discussions [and in Paris soon] so that future generations will not have to suffer the effects of our ill-advised delays.

The recent discovery of traces of water on Mars came too late for even the richest gargantuan capitalist. Such a one cannot hope to rocket there, and slowly to destroy yet another planet. We have, all of us, got this one and only inhabitable planet in our part of the universe. 
In Australia, where this editorial is being written, we have a Government 'Liberal', soi disant, in effect conservative, whose front bench is laced with Catholics, that is Roman Catholics. About H.H. Pope Francis' Laudato Si', we have not heard a squeak from any of them. A previous Liberal Prime Minister, a decent Protestant, John Howard ran a line 'If God has given us all this coal, He must intend that we burn/export it'. One could equally argue 'God has given us a lot of wind, and too much sunlight, so go for renewables'. The recently deposed Prime Minister Tony Abbott (a former Catholic seminarian, Rhodes Scholar, Oxford Blue for Boxing, Monarchist) assured the world: 'Coal is the fuel of the future'. The current Prime Minister Malcolm Turnbull (Catholic, Rhodes Scholar and Republican) is - we pray - simply biding his time, 'till the fossil fools of his party die off. The wait may be fatal for everybody else. Meanwhile Turnbull drives a Prius.

My dear friend Max Charlesworth would have written a more urbane essay than this. He was a continental Catholic. He went to Louvain rather than Oxbridge. I am an Irish Catholic, generally anti-clerical. And I would have voted for gay marriage had diaspora citizens of the Republic been allowed to vote. On my mother's side, we have been, and remained, Catholics since we arrived in Éire with de Courcey. In The Age for 26 October ${ }^{1}$, it is reported that the conservatives at the recent synod on the Family 'found no foundation whatever for same-sex marriage'. The Roman church has, in matters pertaining to sexuality, followed at best the Stoics, and at worst the intuitions of medieaval 'science', such as there was of it. Now we may insist: Human beings are not famed pigs. By the twenty-first century, cardinals ought to have read Freud, Jung, and even the - rather compromised-Kinsey. If 'God is love', then the love between two persons of the same gender ought to be considered with respect. Our Anglican Separated Brethen are wiser in their generation than Roman celibates, with their little red yarmulkes. Homosexuality is a naturally given condition, I am credibly informed. It is not a choice of lifestyle. It may be statistically abnormal, if one expects an absolutely binary split of a human population into M\&F. However, from this, it does not follow that it is 'intrinsically disordered'. ${ }^{2}$ Anymore than is trans-sexuality-a given medical and psychological condition with which surgeons and psychiatrists have to deal and do.

It is curious that a Church which covered up pederasty - the sexual abuse of children - for so many years should have urged a 'No!' vote in the recent referendum on 'gay marriage' in Ireland. I have recently been rereading James Joyce's Stephen Hero, Portrait and Dubliners, and I see the Irish church of today as still bogged down in the 1900s and the stale smell of overcooked cabbage with bacon. One understands Joyce's self-exile. Ireland is now 'a nation once again', and part of Europe. Last time I was in Dublin, I had French food, as well as Irish, scrambled eggs with smoked trout, scones at breakfast. Yum! Can't the Bishops get past colcannon? I must add that a Catholic Bishop whom I saw interviewed on the TV, after the Irish referendum on same-sex marriage seemed simply going through the orthodox motions, and that without any animus at all.

\footnotetext{
1 'Pope ending Synod admonishes bishops with 'closed hearts' The Age 26 October 2015, p.13.

${ }^{2}$ Disordered in respect of what? The possibility of 'the increase of Israel? Why should this matter so much? The world will go on, irrespective. Kant's Categorical Imperative won't come in here since same-sex conduct will not be universal, or universalized, either in theory or in practice.
} 
One happened to see on TV an interview with the American Episcopalian-radical, Bishop Spong. He was so concerned with the attitude of the churches to homosexuality that he spent a couple of years consulting medical experts, psychiatrists, social scientists and so forth. He concluded from his educative process that homosexuals, female and male, are born that way, not made that way. The condition is a given, not a choice. Perhaps, a Roman Catholic Bishop could be spared, and could go on a course as did Bishop Spong.

I was down to write a review of Laudato Si', but my esteemed colleague Purushottama Bilimoria suggested I make it an editorial. Some other time I hope to write on H.H. Pope Francis' rediscovery of Vatican II. Of his quite startling 'Who am I to judge?' à propos homosexuality; of his making it easier for women who have resorted to abortion to receive absolution, this motu proprio; and for his speeding up of petitions for annulment of - dysfunctional - marriages. The Year of Mercy begins on December 8th on what is called 'The Solemnity of the Immaculate Conception'. All such matters were being discussed at the Vatican as I wrote this. To re-run a seminary joke from Vatican II, an Archangel asks the Holy Ghost, 'What did you think of the Synod?' 'The Synod - oh good gracious me, I knew there was somewhere I was supposed to be! I clean forgot!' The hardback turtles seem, so far, to have prevailed at the Synod on the Family. Time - we hope-will tell. There is a wonderful Wizard of Id comic strip: The King of Id and the Duke are on the tower of the castle, overhead is a small white helicopter labelled 'Pope', as H.H. begins to descend on a seat on a rope HM of Id says, 'He is progressive. That hasn't been invented yet!' Out of the pens of satirists... ${ }^{3}$

It is worth noting that in Laudato Si' the logical grammar of 'Nature' follows, mostly, a Royal Society paradigm. There is no resort to the now essentially contestable 'Nature' in 'Natural Law'. The boundaries between 'Natural Law' and 'Law of Nature' are - by the twenty first century due for re-negotiation. So is 'nature' in 'intrinsic nature'. The quotation from Emeritus Pope Benedict XVI (Chapter 4 §155) uses

\footnotetext{
3 The Wizard of Id, The Age, 2 November 2015, p.33. Cartoon internal reference '11.2.15 Parker'.

$* * *$

People who are still 'skeptical' about climate change should read 'A Tide of Horseshit', by David Runciman in The London Review of Books, Vol.37, Number 18, 24 September 2015, pp.34ff.

For a very considered review of Laudato Si' see 'The Pope vs the Market' by William D. Nordhaus, in The New York Review of Books, October 8-21, Vol. LXII, No.15, pp.26-27.

$* * *$

Personal Disclaimer: Of modern Ireland, I am proud to be a citizen thereof... While enjoying the Irish literary malice of Joyce on the Jesuits, I do not share it. To the order and members of it, I am indebted for many kindnesses. That Pope Francis was a Jesuit is a matter for much rejoycement.

$* * *$

Note for Non-Australian Readers:

The Prime Ministership is decided by the party room of whichever party wins a general election. We have had, in recent Australian history, a Labour Government which deposed and replaced a sitting P.M. Kevin Rudd. The replacement, Julia Gillard was then deposed and the formerly deposed P.M. Kevin Rudd reinstated. The Liberal Party has recently deposed a PM and replaced him with another. Tony Abbott has been replaced by Malcolm Turnbull.

The Australian system of Government is based on the Westminster one. However, parties may now try to run the line that the PM is a directly elected quasi-President. He is not. The recently deposed PM, Tony Abbott, tried out the argument that: the people had elected him at a General Election so only the People could remove him (by voting Labour at the next election). The argument-given the logic of the Westminsterarrangements - was fallacious.
} 
'nature' in a more ambiguous way then does Pope Francis. And in a way that owes more to the Stoics than it does to contemporary, clinical, science.

It is interesting that George Cardinal Pell-the Papacy's Treasurer, and erstwhile confessor to Tony Abbott-is reported as saying to H.H. Pope Francis, 'You should have left science to the scientists'. This on the-probably-first occasion when the Church has got the science right! Cardinal Pell is also said to be a climate change skeptic: as was Tony Abbott. 'Climate change is crap' (Abbott). Crap is fertilizer to a farmer: coal as scientist is saying, in the end kills.

We have always known about fertilizer - see the traditional agricultural practices of the Chinese, and the Swiss - the re-cycling of the unmentionable. That coal will finish us off is now a scientific consensus which no educated person can in good conscience doubt. The Pope takes science seriously. So should everyone. The Encyclical is not infallible: it's better than that, it is right. It connects.

We hope that it will transpire that Australia's pathetic offering on $\mathrm{CO}_{2}$ reduction has been (1) received with derision, (2) upped: D.V. At the Paris UN Climate Conference 2015, activists in Paris have awarded Australia the "fossil of the day" award. This was accepted by Greens leader Senator Richard di Natale.

Thanks be to God that the world has voted for serious action on climate change! The news is just in!

Patrick FitzGerald Hutchings 